\title{
The Relationship between Organization Structures and Performance in The Nigerian Public Sector
}

\author{
${ }^{1}$ Olanrewaju Yemisi Esther, ${ }^{2}$ Sanni Mubaraq, ${ }^{3}$ Lateef Saheed Ademola, ${ }^{4}$ Aliu \\ Ismaila Daudu
}

${ }^{1,2,3,4} \mathrm{~K}$ wara State University, Nigeria

${ }^{1}$ feyiyemisi@gmail.com

2Dr.mubaraq@gmail.com

${ }^{3}$ latsad4real@yahoo.com

${ }^{4}$ Ismail4trust@yahoo.com

\begin{tabular}{ll}
\hline ARTICLEDETAILS \\
\hline History & \\
Received & : February \\
RevisedFormat & $:$ March \\
Accepted $\quad$ : April \\
\hline
\end{tabular}

Keywords :

public sector performance, accountability, internal control, communication with stakeholders, nigeria

\begin{abstract}
S
The main purpose of instituting good organizational structure as a parameter for public sector governance control practices is to resolve issues affecting the prudent management of resources to ensure effective public service delivery. However, quality of public service delivery only increased by an aggregate average of 2.4 percent from 2008 to 2017 as a result of poor organization structure. This implies that existence organization structure seems not useful due to the level of decay in public service delivery. Consequently, the present study assesses the relationship between organizational structure tools such communication with stakeholder, accountability and internal control on performance of Nigerian public sector. The study employed the two popular survey research instruments (questionnaire and interview) to collect data concurrently, analyzes separately and merged the results during interpretations. The target population for quantitative analysis is made up of Six (6) from each of the 175 MDAs in Nigeria as at December, 2018 while the study proposed Ten (10) participants for interviews. The quantitative data were analysed using descriptive and inferential statistic. The Partial Least Square Structural Equation Modelling (PLS-SEM) was used to test the hypotheses. The findings of the study from quantitative and qualitative analysis reveal that communication with stakeholder; accountability and internal control are positively and significantly associated with public sector performance. The study concludes that the three constructs proxied for organization structure have positive influence on the public sector performance. Therefore, the study recommends that all the heads of MDAs should lay more emphasis on transparency and accountability in order to be accessible independently by the public, the internal control system of MDAs should be regularly review and updated to achieve the stated public service objective and all MDAs staff should be training regarding the line of communication in public services in order to enhance public sector performance.
\end{abstract}

๑)2020 STIM Lasharan Jaya Makassar

\section{INTRODUCTION}

Fiscal discipline built on solid public governance framework provides the foundation upon which any nation can attain sustainable development. Fiscal discipline associated with good governance ensures that the provision of public services by the government is done in accordance with laid down law in order to improve public sector performance (Bhuiyan and Amagoh, 2011; United Human Rights, 2012). The increasing demand for public sector performance in many countries reveal the nexus between quality public service delivery and good governance in order to meet the demands of the citizen (Otinche, 2016). 
In spite of all efforts by the Nigerian government to improve the quality of public service delivery, it only increased by an aggregate average of 2.4 percent from 2008 to 2017 as revealed in the MO Ibrahim Index of African Governance- IIAG (MO Ibrahim, 2018). In the Index, Nigeria scored 47.9 in overall governance, this is lower than the African regional average (54.3), ranking 33 out of 54 countries in Africa.

One of the problems affecting public sector performance is organization structure. Organization structure is the mechanism of communicating and controlling subordinates, it is in existence but seems not in use due to the level of decay in governance (Hassan, 2015). Organizational structures are expected to shape organizational performance because of the link existing between them. Nguru (2014) emphasized poor internal relationship and authority as the consequences of not using organization structure as means of communication and control, consequently, pervasive corruption and other unethical approaches becomes the order of the day (Bohte and Meier, 2001).

Francis, Ndubuisi and Olasunmbo (2013) also express their stands on inadequate use of organization structure and that weakness in enforcement of rules, corruption and unethical behaviour are the consequences. Therefore, poor organization structure incapacitates public sector entities to maintain effective internal control system that enhance accountability. Poor public sector performance can be linked to unstandardized organization processes that enhance coordination among sub-system within the public sector management. All too often, work is fragmented and compartmentalized and public officers find it difficult to get things done. This hinder the achievement of organizational objectives.

Based on the highlighted problem above, this study attempts at knowing the extent of the relationship between organization structures and public sector performance in the public sector of Nigeria. This would be achieved with the following specific objectives:

i. To assess the influence of Internal control on public sector performance in Nigeria.

ii. To investigate the role of Accountability on public sector performance in Nigeria.

The following research hypotheses in null form were developed from the research objectives.

$\mathrm{H}_{1:}$ Internal control has no significant influence on public sector performance in Nigeria.

$\mathrm{H}_{2}$ : Accountability has no role on public sector performance in Nigeria

\section{LITERATURE REVIEW}

Organizational structure is the structured framework of authority, ties and tasks that governs and manages the activities and behaviors of employees in order to achieve organizational goals (Jones, 2013). The system defines the hierarchical arrangement of workers and duties (Robbins \& Coulter, 2007), the distribution of authority and liability and the implementation by the company's employees of laws and regulations (Nahma, Vonderembse, \& Koufteros, 2003). The organizational structure is manifested in the chart involving three principles in its planning: (i) determination of the formal relationship and reporting showing the levels of hierarchy and span of control, (ii) the units of the organization, position and people of a unit, and (iii) the design of the coordination that guarantees effective relationship (Ahmady, Mehrpour \& Nikooravesh, 2016). The trio further said that the organization structure is affected by its size in addition to goals, strategy, and environment. Organizational structure is about the distribution and coordination of works. Extent organizational structure studies concentrate on centralisation, formalization, and standardization (Jones, 2013).

In centralisation, decision-making power is centralized at the top (Jones, 2013). Formalization refers to "the sum of documentation in the organization" (Daft, 1995). This shows the degree to which the structured rules and procedures describe job tasks (Michael, Cron, Dubinsky \& Joachimsthaler, 1988). Those rules and procedures are written to standardize organizational operations. Standardization is to what degree workers operate according to an organization's standard of procedures and regulations (Hsieh \& Hsieh, 2001). The model sets duties and activities in a necessary manner and time while ensuring that routines and predictability are the acts and behaviors of employees (Jones, 2013). In fact, similar work practices are carried out at all sites in a standardized manner (Daft, 1995). 
Formalization and standardization are management mechanisms for ensuring employee activities lead to achieving organizational goals; formalization and standardization frequently correlate (Price, 1997). Employees are responsible for their acts in an organisation where formalization and standardization are comprehensive, and have no right to violate rules (Jones, 2013).

\section{Internal Control}

Internal control is a mechanism planned and enforced by an entity's management to provide fair certainty as to the accomplishment of a firm's objectives while ensuring quality and effectiveness in its operations. Internal controls ensure the reliability of the financial and management reports, compliance with relevant laws and regulations to protect the integrity of the company (Auditing Practices Board-APB, 1999; COSO, 1992; Cunningham, 2004; INTOSAI, 2004; Kaplan, 2008). Internal control refers to the mechanism and method developed in order to achieve the organization's objective (Amudo \& Inanga, 2009; Baltaci \& Yilmaz, 2006; Glance, 2006; Jokipii, 2010). From the concepts above, one can easily understand that internal regulation is all about regulations that will assist in achieving the goals. It is central to the management processes of the public sector, and should be designed to ensure that productivity and effectiveness are operational in processes.

It is not sufficient for an organization to have a system of internal controls over its critical processes but to ensure that these controls are effective (Candreva, 2006). An efficient structure of internal control that exists when management adopts different procedures helps the external auditor in relying on the work of the internal auditor (Badara \& Saidin, 2013).International Accounting Standards Board-IASB (2012) categorizes the forms of internal control as organizational plan, division of duties, record monitoring, asset protection, personnel competencies, ariary monitoring.

For the purposes of this analysis, effective internal control system refers to control mechanisms developed by an entity for the purpose of safeguarding their assets; ensuring the reliability of their records (financial and non-financial) and compliance with applicable policies and procedures that will ensure the achievement of organizational goals. The five basics for successful internal control as noted by COSO (2004) include Control Climate, Risk Assessment, Control Activities, Knowledge and Communication and Monitoring which are needed to ensure the achievement of organizational goals (Aikins, 2011).

\section{Accountability}

Holding to account is a clarification of what has been or has not been done, holding accountable, being disciplined and being expected to have remedial action if something has gone wrong. Implicitly, accountability can lead to applause or guilt (Jones, 2008). Accountability is accountable to those who have put their faith, confidence and resources into you (Onurah \& Appah, 2012). According to Adegbite (2010), accountability is required to demonstrate that research has been performed in compliance with negotiated rules and standards, and that the officer reports on performance equally and accurately. Onurah and Appah (2012) observed that due to the nature and standards of and from accountability, the capacity to achieve maximum transparency was and continues to be inadequate. Accountability should not only be officials 'naming and shaming, but attempts should be made to promote economic development and reduce institutional recurrence. Adegbite (2010) noted three pillars of accountability, they are responsibility, openness and honesty, named by the United Nations Development Program-UNDP (2001) as ATI. Further responsibility segmentation is in Financial, Administrative, Political and Social Accountabilities.

According to Adeyemi, Akindele, Aluko and Agesin (2012), financial accountability is expected to be a legal responsibility, control over receipts and expenditure, permission to spend public money for public purposes. It is the justification of estimates, the oversight of 
appropriated funds and account auditing. Administrative Transparency requires a solid, internal control structure. This complements the checks and balances, and guarantees them. Political Accountability essentially starts with free, fair and transparent elections. Lastly, Social Accountability is a demand-driven approach which relies on civic engagement and involves ordinary citizens and groups who demand greater accountability for public actions and outcomes. Accountability in the public sector means elected officials have to explain the source and use of public resources at their disposal; democracy empowers people to keep government officials accountable and also to track and regulate their behaviour.

Olatunji and Umar (2014) outline the need for transparency in the Nigerian public service to include I increased fraud and misappropriation by public officials, (ii) knowledge that these unethical practices have contributed to Nigeria's economic woes, (iii) awareness of government activities among people, (iv) pressure from foreign donors demanding more strict adherence to good governance and The steps taken so far by the government to ensure public transparency include simplification of operating procedures, inspection and auditing of accounts, staff and equipment; computerization of public sector operations such as customs services, e-payments, etc.; due process in awarding contracts and procurement, and capacity building, skill training for public servants (Ebonyi, 2000).

\section{Public Sector Performance}

The public sector can be described as those establishments that are saddled with the responsibility of implementing government policies, decisions and delivering services to the citizens. The Nigerian public service is a creation of law (Salisu, 2009) consisting of three (Federal, States and Local) separate levels of government whose powers and relationships are defined and guaranteed by the Constitution. Its main responsibility is policy implementation which is carried out by Ministries/Extra ministerial departments and Agencies - (MDAs) (Imhonopi \& Urim, 2013). The public sector concerns itself with governance with a reflection of complexity of the governance framework and the diversity of approaches taken by public sector entities. There is a renewed interest on the need for an effective and efficient public management in order to strengthen the way the public sector is managed, by tinkering with the organization, performance and working conditions of employees.

The measurement of performance in the public sector has become an important topic lately. There is an increasing pressure and intensive orientation to improve performance, reduce the tax burden, and increase public confidence in government and overall productivity. Profiroiu (2001) gives performance measuring methods as measurements of economy of resources, costs, outputs, effects/outcomes, efficiency, effectiveness and service quality. Performance measurement according to Wang (2002) is a managerial and accountability tool and that is used in budgeting produces efficiency, effectiveness and accountability. Public sector performance is the specific or aggregate outcome from public activity/ies measured either absolutely or in comparison to an earlier outcome (Handler, Koebel, Reiss, $\&$ Schratzenstaller, 2005; Sahban, 2018 ). The use of performance measurement is quite long in history, as long as the early third century, it has evolved in several ways over time (Choong, 2014).

According to Bititci, Garengo, Dorfler and Nudurupati (2012), the evolution of performance management can be seen in four stages which include 'productivity management', 'budgetary control', 'integrated PMS' and the 'integrated performance management'. Practically, performance measurement has some obstacles, the nature of what is being measured and the available information (Cai \& Ye, 2012). The system of measurement is one that gives room for making decisions and taking some actions, efficiency and effectiveness is quantified based on past occurrences (Neely, Adams \& Kennerley, 2002). Currently, public sector performance measurement concerns itself with only effectiveness, efficiency and economy (the " 3 'Es"). This system of measurement has limitations, the indicators are mainly financial; they fail to measure environmental and social fulfillment of environmental and social objectives of the public organizations. According to Cai and Ye (2012), solution to this lies in the adoption of the " 5 E's" system of measurement which 
includes environmental and equity to the " 3 E's". There are goals that are not measurable and as such, benchmarking is resorted to.

\section{THEORETICAL REVIEW}

The fundamental theories and models relating to governance keep on evolving, beginning with the agency theory, extending into stewardship, stakeholder, resource dependency, political or institutional, legitimacy and social contract theories (Lashgari, 2004, Abdullahi $\&$ Valitine, 2009). This section discusses the agency theory that are more relevant to this study.

\section{Agency Theory}

The agency theory deals with the so-called 'agency problem,' the division between ownership and management that was the dominant theoretical viewpoint of the governance structure analysis (Daily, Dalton \& Cannella, 2003). The agency theory has been used in countless economic sectors and the basic principle is the management of the relationship between principal agents in optimizing utility function (Jensen \& Meckling, 1976); separation of ownership from management. The problems of the organization emerge not only from the discrepancies in motive and priorities between the principal and the agent, but also from knowledge asymmetry, the risk expectations of the parties and the planning horizon (Eisenhardt, 1989). The problem with the principal-agent usually applies to problems such as information systems and rewards.

Jensen and Meckling (1976) describe the relationship between the agency as a contract in which one party (the agent) is charged on behalf of another (the principal) with performing a particular task. The theory emphasizes the quest for the contract model which best governs the agreement between the agent and the principal. Both parties are assumed to behave according to rational actions driven by self-interest, which helps to mitigate contract costs (Downs, 1957; Eisenhardt, 1989). Effective corporate governance relies on responsible executives who ensure that public interests are not undermined (Herman \& Renz, 2009). Corporate governance's accountability and transparency aspect will help companies / countries gain the confidence of the stakeholders. Corporate governance increases the trust of stakeholders and that would help the country's survival in the long run. The principal's greatest obstacle is to ensure the agent fulfills their desire. The benefits of a contract based on the agent's actual actions should be contrasted with that of a contract structured to achieve predefined outcomes. In a situation where all information is available and the principal is able to monitor the actions of the agent, Eisenhardt (1989) suggests that the most successful contract model is based on the agent's behaviour; otherwise, the contract must be based on the outcomes being produced.

The agency ensures that organizational processes, supervision and efficient transparency will enhance the efficiency of the public sector in terms of providing the people with good public service (Martin, Gomez-Mejia \& Wiseman, 2013).

\section{METHODOLOGY}

The population for this study is made up of the Permanent Secretary, Director of Finance, Directors of Personnel and of Planning, Research \& Statistics, Accountant and Auditor or equivalents in Ministries, departments and Agencies (MDAs) of the Federal Government of Nigeria, giving a total of Six (6) for each of the 175 MDAs as at December, 2018 (The Embassy of the Federal Republic of Nigeria, 2019). The proportionate stratified method of probability sampling was used to select a sample size of 280 based on "Small Sample Techniques" (Krejcie and Morgan, 1970) out of this population. Relevant data on internal control, accountability and performance in Nigerian public sector were collected using closed ended questionnaire, a popular method of data collection particularly in a case of big 
enquiries of this nature (Kothari, 2004). The questionnaire of two major sections, bio data and research concepts, required short answers, only requiring respondents to tick appropriately.

\section{DATA ANALYSIS}

The quantitative data were analysed using descriptive and inferential statistics. The descriptive statistics organized and presented the data obtained in form of tables, diagrams and graphs. It was also used to quantitatively describe the important features of the study variables using frequency, mean, maximum, minimum and standard deviation. Prior to testing the hypotheses, preliminary tests, normality, multicollinearity, reliability and validity were conducted. The Partial Least Square Structural Equation Modelling (PLS-SEM) was used for inferential statistics.

PLS-SEM is designed for related multiple simultaneous equations offering a number of advantages over more familiar methods, and provides a general framework for linear modelling, allowing great flexibility on how the equations are specified. The development of PLS-SEM as a statistical method has the companion of an evocative graphical language (Monecke and Leisch, 2012). This language allows for the presentation of complex relationships in a convenient and powerful way to others not familiar with PLS-SEM. The ability of PLS-SEM to give a snapshot of collected data makes it appropriate for exploring relationships between two categorical variables, in this context, public sector performance and standard of behaviour. The formulated hypotheses were thus tested, using PLS-SEM.

\section{Mean and Standard of Variables}

There are nine indicators used to measure public sector performance in this study as presented in Table 1. All indicators recorded high levels of mean score with "Capital improvement plans in my agency is fully financed" recordedthe highest mean $(M=4.69$, $\mathrm{SD}=0.522$ ), and "the current financial situation in my agency is acceptable" recorded the lowest mean score of $(\mathrm{M}=4.18, \mathrm{SD}=0.522)$. This shows that capital improvement plans in my agency are fully financed is the main characteristic representing public sector performance.

Table 1 Mean and Standard Deviation of Variables

\begin{tabular}{llllll}
\hline S/N & \multicolumn{1}{c}{ Items } & Min & Max & Mean & S.Dev \\
\hline & & & & & \\
1 & Performance & 1 & 5 & 4.18 & .420 \\
2 & Accountability & 1 & 5 & 4.69 & .522 \\
3 & Communication & 1 & 5 & 4.26 & .503 \\
4 & Internal Control & 1 & 5 & 4.64 & .512 \\
\hline
\end{tabular}

Source: Author's Computation (2020).

Table 3 -Correlation among Constructs

\begin{tabular}{lcclc}
\hline Variables & PSP & AC & CS & IC \\
\hline Public Sector Performance & 1 & & & \\
\hline Accountability & $0.304^{* *}$ & 1 & & \\
\hline $\begin{array}{l}\text { Communication with } \\
\text { stakeholders }\end{array}$ & $0.352^{* *}$ & $0.249^{* *}$ & 1 & \\
\hline Internal Control & $0.361^{* *}$ & $0.182^{* *}$ & $0.359^{* *}$ & 1 \\
\hline
\end{tabular}

Source: Author's Computation (2020).

From the correlations matrix, the coefficients between the exogenous latent constructs are below the suggested threshold of $\geq 0.90$, suggesting independency of the exogenous latent constructs, they are not correlated. 
Table 4 (VIF and Tolerance Values) Multicollinearity Test

Variables

Accountability

\begin{tabular}{ccc}
$\mathbf{N}$ & & $\mathbf{V I F}$ \\
\cline { 1 - 1 } 203 & & 1.281 \\
203 & & 1.325
\end{tabular}

Tolerance Value

Internal Control

.781

.755

Source: Author's Computation (2019).

Table 4 also indicates non-existence of multicollinearity among the exogenous latent constructs, the VIF values are $<5$, tolerance values are $>.20$, and condition indices below 30, Hair et al. (2011). Thus, multicollinearity is not an issue in this study.

\section{Assessment of Measurement Model}

Two approaches to model estimation in SEM have been identified, the variance and covariance based SEMs. The PLS-SEM is a variance-based SEM using the obtained data to estimate the relationships between the coefficients with the aim of reducing the error terms of the endogenous constructs in the model (Hair et al., 2014). A two-step process was used to evaluate and report the results, assessments of the measurement and of the structural models (Henseler, Ringle and Sinkovics, 2009).

\section{Individual item and Internal Consistency Reliability}

An assessment of the model measurement involves individual item determination of reliability, internal consistency and content, convergent and discriminant validities (Hair et al., 2014). The reliability was assessed by examining the outer loading of each construct, items with loading s between 0.40 and $0.70,14$ out of the 29 items were retained based on rule of thumb (Hair, et.al, 2014).

Composite reliability was used to ascertain the internal consistency of measures adapted, this provides a less biased estimate to Cronbach Alpha's coefficient and does not under or overestimate the scale reliability (Gotz, Liehr-Gobbers, \& Kraft,2010).). Table 1 shows the result of the composite reliability and average variance.

Table 5 Summary of the Measurement Model (Composite Reliability and Average Variance Extracted)

\begin{tabular}{|l|l|r|c|c|c|}
\hline Constructs & \multicolumn{1}{|c|}{ Items } & $\begin{array}{c}\text { Factor } \\
\text { Loadings }\end{array}$ & $\begin{array}{c}\text { Composite } \\
\text { Reliability }\end{array}$ & AVE & $\begin{array}{c}\text { Discriminant } \\
\text { Validity }\end{array}$ \\
\hline Internal Control & IC1 & 0.950 & 0.726 & 0.586 & Yes \\
& IC5 & 0.525 & & & \\
& IC7 & 0.743 & & & \\
\hline Accountability & IC9 & 0.755 & 0.788 & 0.658 & Yes \\
& AC1 & 0.947 & & & \\
\hline & AC3 & 0.647 & & & \\
& AC5 & 0.761 & & & \\
& AC6 & 0.743 & & & \\
\hline Public sector & PSF1 & 0.774 & 0.767 & 0.524 & \\
\hline Performance & PSN3 & 0.658 & & & \\
\hline & PSN5 & 0.734 & & & \\
\hline & PFN7 & 0.765 & & & \\
\hline
\end{tabular}

Source: Author's Computation (2020) 


\section{Convergence Validity and Discriminant Validity}

Convergent validity is the extent to which measures of the same latent construct truly and indeed correlate (Hair et al., 2006). This was assessed by examining the Average Variance Extracted (AVE) of each latent construct, as suggested by Fornell and Larcker (1981). It is recommended that the AVE of each latent construct should be $\geq 0.50$ to achieve adequate convergent validity,(Chin,1998).The AVE values exhibited high loadings $(>.50)$ on their respective variable, indicating adequate convergent validity (Table 6).

The Discriminant validity is the extent to which a particular latent construct is different from other latent constructs (Duarte and Raposo, 2010). Fornell and Larcker (1981) suggests an $\mathrm{AVE} \geq 0.50$, and more adequately that the square root of the AVE should be greater than the correlations among the constructs, here the discriminant validity was ascertained by comparing the correlations among the latent constructs with the square roots of AVE in line with Fornell and Larcker, 1981. In addition, Chin's (1998) criterion of comparing the indicator loadings with other reflective indicators in the cross loadings table was used. One, AVE (Table 5) range from 0.540 to 0.724 , suggesting acceptable values, also, the correlations among the latent constructs compared with the square root of the AVE (bolded values -Table 6) suggest adequate discriminant validity, they are greater than the correlations among latent constructs, (Fornell and Larcker, 1981).

Table 6 Correlation among variables

\begin{tabular}{|l|c|c|c|c|}
\hline Accountability & $\mathbf{0 . 8 1 1}$ & & & \\
\hline Internal Control & 0.047 & 0.027 & $\mathbf{0 . 7 6 8}$ & \\
\hline Public Sector Performance & 0.127 & 0.221 & 0.235 & $\mathbf{0 . 7 2 4}$ \\
\hline
\end{tabular}

Organization structure is comprised of accountability and internal control as sub hypotheses. Figure 1 and Table 7 show the relationship between organizational structure and public sector performance.

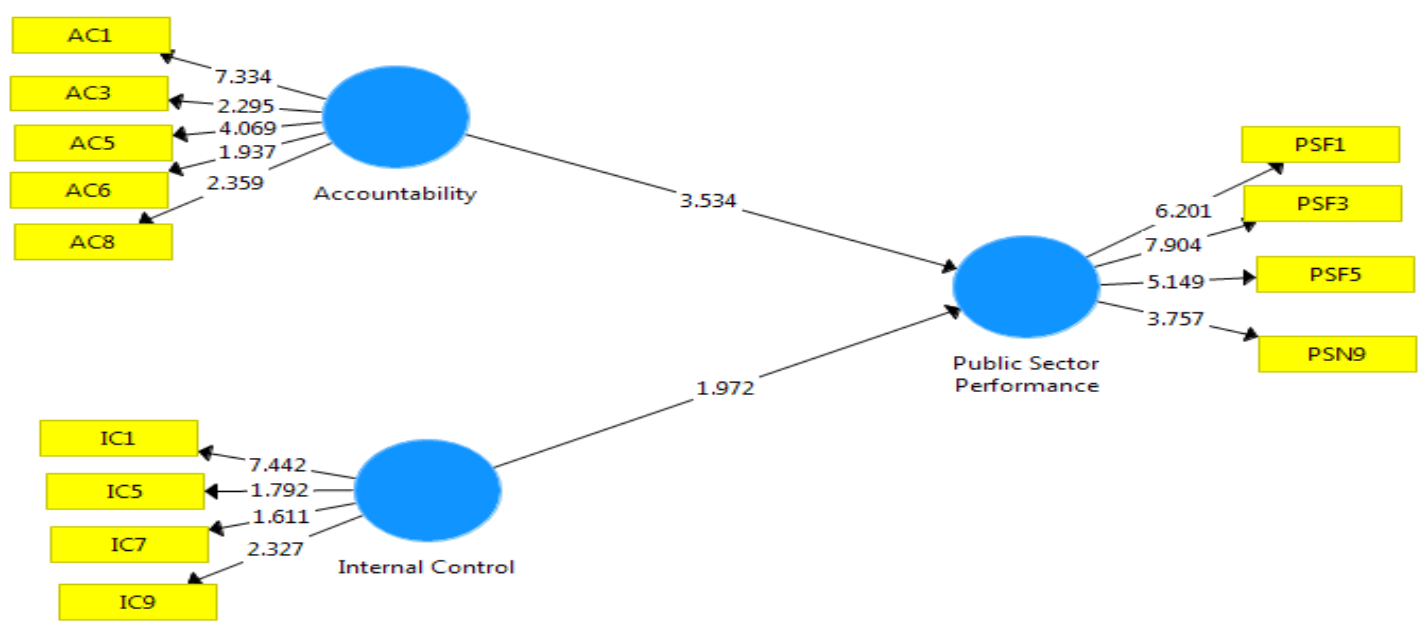


Figure 1 Assessment Structural Model (Organizational Structure and Public Sector Performance)

Table 7 Assessment Structural Model (Organizational Structure and Public Sector Performance)

\begin{tabular}{|l|r|r|r|r|}
\hline Hypotheses & Beta & $\begin{array}{c}\text { Standard } \\
\text { Error }\end{array}$ & $\begin{array}{c}\text { T } \\
\text { Statistics }\end{array}$ & $\begin{array}{c}\text { P } \\
\text { Values }\end{array}$ \\
\hline Accountability -> Public Sector Performance & 0.218 & 0.062 & 3.534 & 0.001 \\
\hline Internal Control -> Public Sector Performance & 0.139 & 0.070 & 1.972 & 0.054 \\
\hline
\end{tabular}

Source: Author's Computation (2020)

Figure 1 and Table 7 show the results of hypothesis which predicted that Organizational structure is positively related to public sector performance. They indicate that Accountability has significant relationship with public sector performance $(\beta=0.218, t=$ 5.34, $\mathrm{p}<0.036)$. Also, there is a significant positive relationship between internal control and public sector performance $(\beta=0.139, \mathrm{t}=1.97, \mathrm{p}<0.054)$.

\section{Effect Size $\left(\mathbf{f}^{2}\right)$}

Effect size $\left(\mathrm{f}^{2}\right)$ is the strength of a particular exogenous variable on endogenous variable(s) measured changes in the coefficient of determination $\left(\mathrm{R}^{2}\right)$ (Chin, 1998). Cohen (1988) describes $\mathrm{f}^{2}$ values of $0.02,0.15$ and 0.35 as weak, moderate and strong effects respectively. Table 3 shows the respective effect sizes of the variables in the model.

Table 8 - Effect Size $\left(\mathbf{f}^{2}\right)$

\begin{tabular}{|l|c|c|}
\hline Variables & Effect size $\left(\mathbf{f}^{2}\right)$ & Decision \\
\hline Accountability & 0.07 & Weak \\
\hline Internal Control & 0.26 & Moderate \\
\hline
\end{tabular}

As indicated on Table $8, \mathrm{f}^{2}$ for accountability and internal control are 0.07 and 0.26 respectively, conclusively, the effect sizes of the two variables on public sector performance can be considered as weak and moderate (Cohen, 1988).

\section{Predictive Relevance $\left(\mathbf{Q}^{2}\right)$}

A cross-validated redundancy measure $\left(Q^{2}\right)$ was applied to assess the predictive relevance of the research model. Table 9 presents the results of the cross-validated redundancy $Q^{2}$ test, the cross-validation redundancy measure $Q^{2}$ for all variables were above zero, suggesting predictive relevance of the model (Chin, 1998; Henseler et al., 2009).

Table 9 Predictive Relevant $\left(Q^{2}\right)$

\begin{tabular}{lccc}
\hline Variables & SSO & SSE & $\mathbf{Q}^{2}=(\mathbf{1 - S S E} / \mathbf{S S O})$ \\
\hline $\begin{array}{l}\text { Public Sector Performance } \\
\text { (PSP) }\end{array}$ & 890.000 & 714.675 & 0.028 \\
\hline
\end{tabular}

Table 10 Summary of Hypotheses Testing

\begin{tabular}{lllll}
\hline Hyp. & \multicolumn{1}{c}{ Relationship } & T Statistics & P Values & Decision \\
\hline & Organizational Structure & & & \\
$\mathbf{H}_{\mathbf{i}}$ & Accountability -> Public Sector Performance & 0.365 & 0.716 & Supported \\
$\mathbf{H}_{\mathrm{ii}}$ & Internal Control -> Public Sector & 2.098 & 0.036 & Supported \\
& Performance & & & \\
\hline
\end{tabular}


From Table 10, two hypotheses to test the relationship between organizational structure and public sector performance accountability and internal control showed significant relationship.

\section{DISCUSSION OF FINDINGS}

The study employed quantitative data collected through questionnaire Setting the relationship between organizational structure and efficiency of the public sector using two variables: transparency and internal control. The PLS-SEM result showed that Accountability has a substantial relationship with the efficiency of the public sector $(\beta=$ $0.218, \mathrm{t}=5.34, \mathrm{p}<0.036)$ at a significance level of 5 per cent. The research failed to acknowledge the null hypothesis that suggests there is no meaningful connection between transparency and efficiency in the public sector. Which means which transparency positively affects the level of success in the public sector. PLS-SEM also showed a important positive relation between internal control and the output of the public sector $(\beta=$ $0.139, \mathrm{t}=1.97, \mathrm{p}<0.054)$. The hypothesis is now restated that the relationship between internal control and the output of the public sector is important. It also means that an improvement in unit compliance with current internal control affects public sector output by 14 per cent.

The results of this study are in line with some earlier studies such as Yao, Yusheng and Bah (2013), which concluded that there are also important relationships between internal control systems and successful financial management of the public sector. Despite conflicting results from Meier's research (2001) that used mixed methods, he still concluded that period of influence forms success in a wide range of public organisations. Other studies which also support the findings of this study include Simangunsong (2014) and Boakye (2016) in Ghana, which concluded that the internal control effectiveness and internal audit function had a positive impact on local government performance both simultaneously and in part. Also, as a result of effective supervision, division of responsibilities, proper authorizations and approval etc., the internal control structure was efficient at the public hospital. However, Boakye (2016) clearly indicated that some problems hindered its implementation, such as poor judgment in decision-making, making errors due to carelessness, exhaustion, etc. The results of this study are also in tandem with Munene (2013), who analyzed and published on the relationship between internal control mechanisms and financial performance in Kenya's technical training institutions In line with this, the Mohunyo and Jagongo (2018) research also stated that internal control has a major impact on financial performance in public institutions. Emmanuel, Ajanya, and Audu (2013) have reiterated that internal control is a mechanism for monitoring fraudulent activities and therefore increasing transparency.

Continuous records of failure in governance, lack of transparency and accountability, inefficiency and corruption are the product of poor, politicized, wasteful and ineffective government management processes in the public sector in Nigeria. There is an organizational framework in the form of internal control and transparency designed to address these issues in order to enhance public sector service delivery, but it does not seem to work. This study aims to investigate the relationship between the structure of Nigerian public sector organizations and results. They formulated two goals, study questions, hypotheses. Data were obtained via a standardized questionnaire administered to 270 respondents, consisting of Federal MDAs high-caliber representatives.

Using concise and inferential statistics, the questionnaire data were analysed. The descriptive statistics include basic description on the variables and the inferential statistics provide correlation, t-test and PLS-SEM for study to check all the hypotheses.

The findings showed important positive relationships between internal controls, and transparency for success in the public sector. The report ended with: 
1. That when public office holders are accountable, the performance in public sector improved.

2. Compliance with the internal control put in place in public service influences the extent of performance in public sector.

\section{REFERENCES}

Abdallah, H. \& Valentine, B. (2009). Fundamentals and ethics theories of corporate governance. Middle Eastern Finance and Economics, 4(7), 88-96.

AbdAziz, M. A., AbdRahman, H, Alam, M. \& Said, J. (2015) Enhancement of the Accountability of Public Sectors through Integrity System, Internal Control System and Leadership Practices: A Review Study. 7th International Conference on Financial Criminology 2015. Procedia Economics and Finance 28 (2015), 163 169. doi: 10.1016/S2212-5671(15)01096-5

Adegbite, E. O. (2010). "Accounting, Accountability and National Development”, Nigerian Accountant, 43(1), 56-64.

Adeyemi, O.O., Akindele S. T., Aluko O. A. \& Agesin, B. (2012) Institutionalizing the culture of accountability in local government administration in Nigeria; African Journal of Political Science and International Relations, 6(4),81-91. DOI: 10.5897/AJPSIR11.127

Aikins, S. K. (2011). An examination of government internal audits' role in improving financial performance. Public Finance and Management, 11(4), 306-337.

Amudo, A., \& Inanga, E. L. (2009). Evaluation of Internal Control Systems: A case study from Uganda, International Research Journal of Finance and Economics, ISSN1450-2887

Aziz, M. A. A., Rahman, H.A., Alam, M.M., \& Said, J. (2015). "Enhancement of the accountability of public sectors through integrity system, internal control system and leadership practices: A review study." Procedia Economics and Finance, 28(1), 163-169.

Badara, M. S, \& Saidin, S. Z. (2013). Impact of the effective internal control system on the Internal audit effectiveness at local government level. Journal of Social and Development Sciences, 4 (1), 16-23.

Barrett, P. (2002) Achieving Better Practice Corporate Governance in the Public Sector. International Quality \& Productivity Centre Seminar: Office Auditor General Australian

Bhuiyan, S. H. \& Amagoh, F. (2011). "Public sector reform in Kazakhstan: issues and perspectives." International Journal of Public Sector Management, 24(3), 227-249.

Bititci, U., Garengo, P., Dorfler, V. \& Nudurupati, S. (2012). 'PM: challenges for tomorrow', International Journal of Management Review, 14(3), 305-327.

Boakye, E. (2016). The role of internal control in the public sector: A case of Edeweso Government hospital.

Bohte, J. \& Meier, K. (2001) Structure and the Performance of Public Organizations: Task Difficulty and Span of Control. Public Organization Review, 1(September 2001), 341-354

Bohte J., \& Meier, K.J., (2001). Structure and the performance of public organizations: task difficulty and span of control. Public organization review, 1 (3), 341- 354.

Cai, Z., \& Wang, Y. (2012). Research frontiers in public sector performance measurement. 2012 International Conference on solid state devices and materials science. Science direct, Physics Procedia, 25 (2012) 793-799

Candreva, P. J. (2006). Controlling internal controls. Public Administration Review, 66(3), 463-465.

Chin, W. W. (1998). The partial least squares approach to structural equation

Choong, K.K., (2014). Fundamentals of PMSs, International journal of productivity and performance management, 63(7),.879-922.

Clarke, T., \& Rama, D. (2006). Corporate Governance and Globalisation. London, UK: Sage publications. 
Cohen, J. (1988). Statistical power analysis for the behavioural sciences. Hillsdale, NJ: Lawrence Erlbaum Associates.

Committee of Sponsoring Organizations of the Treadway Commission -COSO (2004). Enterprise risk management integrated framework: executive summary. Sponsoring Organizations of the Treadway Commission. Jersey City. New Jersey.

Cunningham, L.A., (2004). The appeal and limits of internal controls to fight fraud, terrorism, other ills

Daft, R. (1995). Organization theory and Design, ( $5^{\text {th }}$ ed.), New York, West Publishing Company.

Daily, C., Dalton, D., \& Rajagopalan, N. (2003). "Governance through ownership: centuries of practice, decades of research", Academy of Management Journal, 46(1), 115-158.

Davis, J.H., F. Schoorman, \& Donaldson L (1997), Toward a stewardship theory of management, Academy of Management Review, 22(1), 20-47.

Donaldson, L. \& Davis J.H. (1991), Stewardship theory or agency theory: CEO governance and shareholder returns, Australian Journal of Management, 16 (1), 49-65.

Downs, A. (1957). An economic theory of democracy. New York: Harper Collins Publishers

Duarte, P., \& Raposo, M. (2010). A PLS model to study brand preference: An application to the mobile phone market. In V. Esposito Vinzi, W. W. Chin, J. Henseler \& H. Wang (Eds.), Handbook of Partial Least Squares (449-485).

Ebonyi, O. (2000). The struggle for public accountability through ages. O. Ebonyi, (Eds.) Public Accountability. Nsukka; Uzziboh Publishers.

Embassy of the Federal Republic of Nigeria (2019). List of Federal Ministries in Nigeria, www.nigeriaembassyusa.org retrieved on $14^{\text {th }}$ August, 2018.

Emmanuel, E., O., Ajanya, M.A., \& Audu, F., (2013) An assessment of internal control audit on the efficiency of public sector in Kogi state Nigeria. Mediterranean Journal of social sciences, 4(11), 1-13. doi: 10.5901/miss. 2013.v4n11p717

Fama, E. (1980) Agency problems and the theory of the firm. Journal of Political Economy, $88(1), 2-10$.

Fornell, C., \& Larcker, D.F. (1981). Evaluating structural equation models with unobservable variables and measurement error. Journal of marketing research. $18(1), 39-50$

Gotz, O., Liehr-Gobbers, K., \& Krafft, M. (2010). Evaluation of Structural Equation Models using the Partial Least Squares (PLS) Approach. In V. E. Vinzi, W. W. Chin, J. Henseler \& H. Wang (Eds.), Handbook of Partial Least Squares: Concepts, Methods and Applications (691-711).

Hair, J. F., Black, W. C., Babin, B. J., \& Anderson, R. E. (2010). Multivariate data analysis (7th ed.). Upper Saddle River, New Jersey: Prentice Hall.

Hair, J. F., Hult, G. T. M., Ringle, C. M., \& Sarstedt, M. (2014). A primer on partial least squares structural equation modelling (PLS-SEM). Thousand Oaks: Sage Publications.

Hair, J. F., Money, A. H., Samouel, P., \& Page, M. (2007). Research method for business. West Sussex, England: John Wiley \& Sons Ltd.

Hair, J. F., Ringle, C. M., \& Sarstedt, M. (2011). PLS-SEM: Indeed, a Silver Bullet. Journal f Marketing Theory and Practice, 18(1), 139-152.

Hair, J. F., Ringle, C. M., \& Sarstedt, M. (2013). Partial least squares structural equation modelling: Rigorous applications, better results and higher acceptance. Long Range Planning, 46(1-2), 1-12. doi: http://dx.doi.org/10.1016/j.lrp.2013.01.001

Hall, P. A. \& Taylor R. C. R. (1996) Political science and the three new institutionalisms, Political Studies 44(1), 952-73.

Handler, H., Koebel, B., Reiss, J.P., \& Schratzenstaller, M. (2005). The size and performance of public sector activities in Europe. An overview Acta Oeconomica, 56 (4), 399-422.

Henseler, J., Ringle, C. M., \& Sinkovics, R. R. (2009). The use of partial least Squares path modelling in international marketing. In R. R. Sinkovics \& P. N. Ghauri (Eds.), Bingley: Emerald. Advances in International Marketing, 20(10), 277-320). 
Herman R. D., \& Renz D. O. (2009). Advancing non-profit organizational effectiveness research and theory: Nine theses. Non-profit Management and Leadership, 18(4), 399-415.

Hillman, A.J., Canella, A.A., \& Paetzold, R.L. (2000) "The resource dependency role of corporate directors: Strategic adaptation of board composition in response To environmental change". Journal of Management Studies, 37(2), 235-255

Hodges, R. \& Wright, M. (1995) Audit and Accountability process: the role of National Audit Office. Financial Accountability and Management, 11(2),153-170.

Hsier, Y.M., \& Hsier, A.T., (2001). Enhancement of service quality with job standardization. The service industry journal, 21(3), 147-166

Imhonopni, D. and Urim, U.M. (2013). 'Leadership crisis and corruption in the Nigerian public sector. An albatross of national development' The African symposium,13(1), $78-87$.

INTOSAI (2007) -ISSAI11 Guidelines and Good Practice Related to SAI Independence Jensen, M.C. \& Meckling, W. H. (1976). Theory of the firm: Managerial behavior, agency costs, and ownership Structure.

Ishola, S.A., Abikoye, O.A., \& Olajide, R.A. (2015). Effect of internal control system in Nigeria public sectors: A case study of Nigeria National Petroleum Corporation. International journal of Economics, Commerce and Management, III (6), 10931105 .

Johansson, R. (2002). Nyinstitutionalismen inom organisationsanalysen: en skolbildnings uppkomst, spridning och utveckling. Lund, Studentlitteratur.

Jokipii, A. (2010). Determinants and consequences of internal control in firms: a contingency theory based analysis. Journal of Management Governance, 14(1), $115-144$

Jones, M. J. (2008). Internal control, accountability and corporate governance: Medieval and modern Britain compared. Accounting, Auditing \& Accountability Journal, 7(1), $1052-1075$

Jones, G. (2013). Organization theory, design and change, ( $7^{\text {th }}$ edition), Pearson, Harlow, England.

Kaplan Publishing. (2008). Professional Accountant (PA). The complete text. Berkshire. Kaplan publishers.

Kato, J. (1996) Review Article: Institutions and rationality in politics - Three varieties of Neo-institutionalists, British Journal of Political Science, 26(1), 553-82.

Kothari, (2004). Research Methods: methods and techniques. New Delhi: AGE International.

Krejcie, R. V., \& Morgan, D. W. (1970). Determining sample size for research activities. Educational and Psychological Measurement 30(1), 607-610

Lashgari, M. (2004) Corporate Governance: Theory and Practice. The Journal of American Academy of Business, Cambridge Press

March, J. G. \& J. P. Olsen (1996) Democratic Governance (New York: Free Press).

Martin, G.P., Gomez-Mejia, L.R., \& Wiseman, R.M. (2013). Executive stock options as mixed gambles: Revisiting the behavioural agency model, Academy of Management journal, 56 (2), 189-209,

Michaels, E., Cron, L., Dubinsky, J., \& Joachimsthaler, A. (1988). Influence of formalization on the organizational commitment and work alienation of salespeople and industrial buyers. Journal of vocational behaviour, 61(3), 20-52.

Mohunyo, B.M., and Jagongo, A.o., (2018). Effect of internal control systema on financial performance of public institutions of higher learning in Nairobi City county, Kenya. International academic journal of human resource and business administration, $3(2), 273-287$

Monecke, A., \& Leisch, F. (2012). "SEM-PLS: Structural Equation Modelling Using Partial Least Squares". Journal of statistical software, 48(3), 1-32. URL http:www.jstatsoft.org/v48/i03/.

Munene, M.J., (2013). Effect of internal controls on financial performance of technical training institutions in Kenya. An un-published masters' dissertation. 
Nahma, A., Vonderembse, M., \& Koufteros, X., (2003). The impact of organizational structure on time-based manufacturing and plant performance, Journal of operations Management, 21(5), 281-306.

Olatunji, O. \& Umar, M. B. (2014) Corruption, accountability and transparency in the present democratic era (1992 To Date) in Nigeria's Public Service. International Journal of Humanities Social Sciences and Education (IJHSSE) 1(8), 109-114.

Onuorah, A. C. \& Appah, E. (2012) Accountability and Public Sector Financial Management in Nigeria. Arabian Journal of Business and Management Review, 1(6), 1-17

Otinche, S. I. (2016). Discuss on fiscal discipline and corporate governance in the public sector in Nigeria. Corporate ownership and control, 13(3), 561-571.

Peters, B. G. (2000). Institutional Theory and Public Organizations, in G. Morand and P. Knopfel. eds., Essays in Memory of Raimund German

Robbin. S., \& Coulter, M. (2007). Management, ( $9^{\text {th }}$ ed.), Pearson, New Jersey, USA

Sahban, M. A. (2018). Kolaborasi Pembangunan Ekonomi di Negara Berkembang (1st ed.;

P. Rapanna, ed.). Retrieved from

https://books.google.co.id/books/about/Kolaborasi_Pembangunan_Ekonomi_di_Ne gara.html?id=WVRtDwAAQBAJ\&redir_esc $=y$

Salisu. S. (2009). Nigeria: Why the public sector is inefficient. Village Square. http://nigeriavillagesquare.com/articles/salisu-suleiman/nigeria-why-the-publicsector-isinefficient.html [Accessed March 2, 2018].

Scott, W. R. (2001). Institutions and organizations. Thousand Oaks, Calif., Sage Publications.

Simangunsong, R. (2014) The Impact of Internal Control Effectiveness and Internal Audit Role toward the Performance of Local Government. Research Journal of Finance and Accounting; 5(7), 50-60.

Thoenig, J. C. (2011) Institutional Theories and Public Institutions. (Ed) B. Guy Peters and Jon Pierre. The Handbook of Public Administration. Sage Publication

United Nations Development Programme. (2001). Country assessment in accountability and transparency. New York: United Nations.

Wang, X., (2002). Performance measurement impact. A study of U.S. local governments. Public performance and management review, 26(1), 26-43.

Yao, P.L., Yusheng, K., \& Bah, F.B.M. (2017). A critical examination of internal control systems in the public sector, a tool for alleviating financial irregularities: evidence from Ghana. Research journal of finance and accounting, 8(22), 94-110. 